\title{
Acute Appendicitis in a COVID-19 Patient-Surgical Dilemma and Operative Challenges
}

\author{
Nursel Calik Basaran ${ }^{1}$ (D) $\cdot$ Hilmi Anil Dincer $^{2}$ (D) Timucin Erol $^{2}$ (D) $\cdot$ Gulay Sain Guven ${ }^{1}$ (D)
}

Received: 12 July 2020 / Accepted: 11 December 2020/Published online: 16 January 2021

(C) Association of Surgeons of India 2021

To the Editor,

The diagnosis of acute abdominal pathologies may be problematic in COVID-19 patients as fever and abdominal pain, and elevation of acute phase reactants can be seen in both conditions. Treatment is challenging because operative interventions carry risks for the patient and healthcare workers (HCW). Here, we summarized a confirmed COVID-19 patient with acute appendicitis early after antiviral treatment.

A 75-year-old man presented with fever, fatigue, and myalgia since 3 days. He had hypertension and grade 2 chronic renal disease for many years. The physical examination was unremarkable except fever $\left(38.5^{\circ} \mathrm{C}\right)$. Thorax computerized tomography $(\mathrm{CT})$ revealed typical infiltration for COVID19; nasopharyngeal swab was positive for SARS-CoV-2. He was hospitalized, treated with favipiravir for 5 days according to Turkish National Guideline on COVID-19, and fever was resolved [1].

Two days after antiviral treatment, fever up to $39^{\circ} \mathrm{C}$ and progressive diffuse abdominal pain emerged. Abdominal examination revealed mild tenderness without defense and rebound. Leukocyte count was $4400 \mu \mathrm{L}$, lymphocytes $306 \mu \mathrm{L}$, CRP $8.79 \mathrm{mg} / \mathrm{dL}(0-0.8)$, ferritin $516 \mu \mathrm{L}(20-336)$. After consultation with general surgery, abdominal CT was performed and acute distal appendicitis with an appendicolith was diagnosed (Fig. 1). Oral intake was discontinued, and parenteral antibiotics (ceftriaxon + metronidazole) were started. During follow-up, abdominal stiffness, tenderness, and defense emerged within $24 \mathrm{~h}$, and decision to perform

Nursel Calik Basaran

nurselcbasaran@gmail.com

1 Faculty of Medicine, Department of Internal Medicine, Division of General Internal Medicine, Hacettepe University, Sıhhıye, Çankaya, 06100 Ankara, Turkey

2 Faculty of Medicine, Department of General Surgery, Hacettepe University, Ankara, Turkey appendectomy has given. Vital signs, leukocyte and creatinine level were as follows before surgery: pulse 90/min, body temperature $37.8{ }^{\circ} \mathrm{C}$, leukocyte count $5200 \mu \mathrm{L}$, creatinine $1.15 \mathrm{mg} / \mathrm{dL}$. Written informed consent was taken from the patient. For renal protection, volume and blood pressure controlled optimally and avoided from nephrotoxic drugs during and after surgery. The operative team consisted only essential staff: two surgeons, one anesthesiologist, one nurse, and one technician dressed with full personal protective equipment (face shield, eye glasses, FFP3 mask, two gloves, coif, surgical overalls). Patient transferred according to our hospitals' protocol to the operation theater, designated for COVID-19. Operation theater has negative pressure, viral filters, restricted access, and separate dressing room. All equipment and medications used during operation were ready inside the room ahead of the surgery. Open appendectomy was performed in 25 min by senior surgeon under spinal anesthesia according to international guidelines [2]. The patient recovered without any complications.

The clinical spectrum of COVID-19 is heterogeneous. Beside fever, cough, fatigue, shortness of breath, recently, nausea and vomiting was added to possible COVID-19 symptoms [3]. The emerging of new symptoms in our patient was compatible with the worsening of COVID-19 [4]. However, common symptoms and the strict isolation procedures can lead to mis- or underevaluation of the COVID-19 patients. Physicians should keep in mind all other abdominal pathologies in the differential diagnosis of abdominal pain in COVID19 patients.

Surgery is still the gold standard for most of the appendicitis cases [5, 6]. During COVID-19 pandemic, surgery, especially in an elderly patient with active pneumonia, had higher risk of morbidity, mortality, and viral transmission [7]. Emergency surgeries are inevitable, must be performed under universal isolation precautions for COVID-19 [8]. Spinal anesthesia may prevent from the risks of aerosol generation and must be used whenever possible [9]. Operating these patients by a senior surgeon with a small team may also shorten 


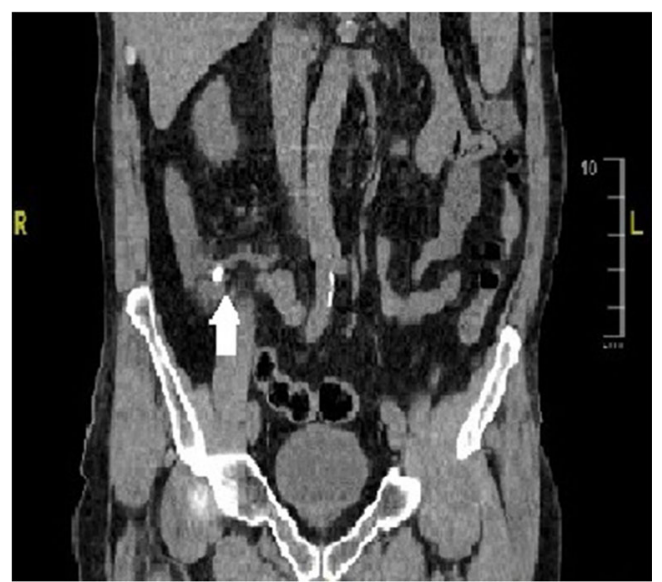

Fig. 1 White arrow, appendicolith in proximal appendix lumen

operating time, reduce the possible complication rates, and viral transmission risk of HCW. Cooperative and multidisciplinary approach has been very important to provide best results under these extraordinary conditions.

\section{Compliance with Ethical Standards}

Conflict of Interest The authors declare that they have no conflict of interest.

\section{References}

1. Republic of Turkey Ministry of Health Directorate General of Public Health (2020). COVID-19 (SARS-CoV-2 infection) guide (in Turkish). Website https://covid19bilgi.saglik.gov.tr/depo/rehberler/ COVID-19_Rehberi.pdf. [Accessed 14 April 2020]

2. Moletta L, Pierobon ES, Capovilla G, Costantini M, Salvador R, Merigliano S, Valmasoni M (2020) International guidelines and recommendations for surgery during Covid-19 pandemic: a systematic review. Int J Surg 79:180-188. https://doi.org/10.1016/j.ijsu.2020. 05.061

3. Stokes EK, Zambrano LD, Anderson KN, Marder EP, Raz KM, el Burai Felix S, Tie Y, Fullerton KE (2020) Coronavirus disease 2019 case surveillance - United States, January 22-May 30, 2020. MMWR Morb Mortal Wkly Rep 69:759-765

4. Wang D, Hu B, Hu C, Zhu F, Liu X, Zhang J, Wang B, Xiang H, Cheng Z, Xiong Y, Zhao Y, Li Y, Wang X, Peng Z (2020) Clinical characteristics of 138 hospitalized patients with 2019 novel coronavirus-infected pneumonia in Wuhan, China. JAMA 323(11): 1061-1069

5. Sartelli M, Chichom-Mefire A, Labricciosa FM, Hardcastle T, AbuZidan FM, Adesunkanmi AK, Ansaloni L, Bala M, Balogh ZJ, Beltrán MA, Ben-Ishay O, Biffl WL, Birindelli A, Cainzos MA, Catalini G, Ceresoli M, Che Jusoh A, Chiara O, Coccolini F, Coimbra R, Cortese F, Demetrashvili Z, di Saverio S, Diaz JJ, Egiev VN, Ferrada P, Fraga GP, Ghnnam WM, Lee JG, Gomes CA, Hecker A, Herzog T, Kim JI, Inaba K, Isik A, Karamarkovic A, Kashuk J, Khokha V, Kirkpatrick AW, Kluger Y, Koike K, Kong VY, Leppaniemi A, Machain GM, Maier RV, Marwah S, McFarlane ME, Montori G, Moore EE, Negoi I, Olaoye I, Omari AH, Ordonez CA, Pereira BM, Pereira Júnior GA, Pupelis G, Reis T, Sakakushev B, Sato N, Segovia Lohse HA, Shelat VG, Søreide K, Uhl W, Ulrych J, van Goor H, Velmahos GC, Yuan KC, Wani I, Weber DG, Zachariah SK, Catena F (2017) The management of intraabdominal infections from a global perspective: 2017 WSES guidelines for management of intra-abdominal infections. World J Emerg Surg 12:29

6. Salminen P, Tuominen R, Paajanen H et al (2018) Five-year followup of antibiotic therapy for uncomplicated acute appendicitis in the APPAC randomized clinical trial [published correction appears in JAMA. 2018 Oct 23;320(16):1711]. JAMA 320(12):1259-1265. https://doi.org/10.1001/jama.2018.13201

7. COVIDSurg Collaborative. Mortality and pulmonary complications in patients undergoing surgery with perioperative SARS-CoV-2 infection: an international cohort study. Lancet. 2020 Jul 4;396(10243):27-38. doi: https://doi.org/10.1016/S01406736(20)31182-X

8. Coccolini F, Perrone G, Chiarugi M, di Marzo F, Ansaloni L, Scandroglio I, Marini P, Zago M, de Paolis P, Forfori F, Agresta F, Puzziello A, D’Ugo D, Bignami E, Bellini V, Vitali P, Petrini F, Pifferi B, Corradi F, Tarasconi A, Pattonieri V, Bonati E, Tritapepe L, Agnoletti V, Corbella D, Sartelli M, Catena F (2020) Surgery in COVID-19 patients: operational directives. World J Emerg Surg 15: 25

9. Khan U, Gok M (2020) Coronavirus and surgery. Eur Surg 52:240 242. https://doi.org/10.1007/s10353-020-00647-y

Publisher's Note Springer Nature remains neutral with regard to jurisdictional claims in published maps and institutional affiliations. 